as suitable in-members in order to participate in the social, cultural and political life of their countries and who should not.

The analysis examines the "front stage' where the public/voters are present and the 'back stage' where politics is done. Political actors are seen as performers on the front stage conveying empathy, anger and discontent in relational terms using phrases and tunes that capture the ideas that 'we' are against the elites, against those up there - the 'them' and 'us' rhetoric being used to convince voters that they, the political actors, are like them and thus understand the 'fear' of the ordinary person/of us. The press coverage thus gained of their messages helps further their control of the political and media agenda.

The final chapter concludes with a message addressed to the media, public opinion and political actors to dismantle these politically manipulative dynamics. Wodak provides a way forward to change the current discourses of fear through strategies such as the use of discourses that are inclusive, the use of 'we' terms and not the divisive 'us vs them', the use of language that promotes values of well-being, dignity, equality, diversity and solidarity.

Wodak is a prolific researcher and writer in the field of critical discourse analysis with much of her work focused on the study of political extremism. This book is an accessible read, encompassing her extensive knowledge of what has been published in the area with her examination of the politics of fear.
Her writing is targeted not just at academia but to those outside this sphere. As Wodak states in her preface: 'I have made a point of employing a more popular comprehensible style of writing while still doing justice to the requirements of systematic linguistic analysis' (p. xii). Wodak also provides informative and clear tables of linguistic strategies, including a useful explanatory table on fallacy in chapter three.

The book is useful for students interested in linguistics and political discourse and for media and communication professionals because it helps understand the range of rhetorical devices used by political actors to reshape and communicate their content, the logical fallacies used in political discourses and what needs to be done to challenge the language and the discourses.-LYNNE TRENWITH is an Auckland-based communications academic and consultant.

\section{Questions of great intricacy opened up to non-Arabic audience}

Media and Political Contestation in the Contemporary Arab World, edited by Lena Jayyusi and Anne Sofie Roald. Basingstoke/ New York: Palgrave MacMillan 2016. 327 pages. ISBN 978-1-137-5252-2-2.

\section{MEDIA and Political Contestation} in the Contemporary Arab World explores the extremely complicated reality of the Arab media and its place in the political and cultural debates that are rarely recognised or understood in the west. In the Middle East, media of 
all kinds, from clothes to pop songs, carry heavily loaded political messages that simply cannot be avoided and which can cause political explosions.

In 2010, for instance, Iraqi singer Shadha Hassoun released a video called 'Aarqoub's Promise,' which shows an Iraqi woman regretting her liaison with an American soldier. The video caused an uproar which spilled over into mosque sermons, political speeches and the Iraqi elections.

Messages freighted with political meaning confront residents of the Middle East all day long. Media products we might dismiss or take for granted become sites of immense cultural and political contestation.

The special circumstances of many Arab states have led to specialisations that have no equal in the west. During the second intifada a young Palestinian, Muhammad al-Durrah, was killed by crossfire between Israeli soldiers and Palestinian fighters. Almost instantaneously, posters using a still image from a video tape shot by a France 2 cameraman appeared, showing him clinging to his father in the midst of the battle.

Al-Durrah had become the subject of what Haddad calls a martyr's poster, a carefully choreographed, but vital, tool for celebrating and memorialising Palestinians killed in the conflict with the occupying Israeli forces.

But they are more than just that, of course, because the iconography, the language, the way images have been photoshopped, all reflect what he calls 'a dialectic within the Palestinian public sphere where intricate social and

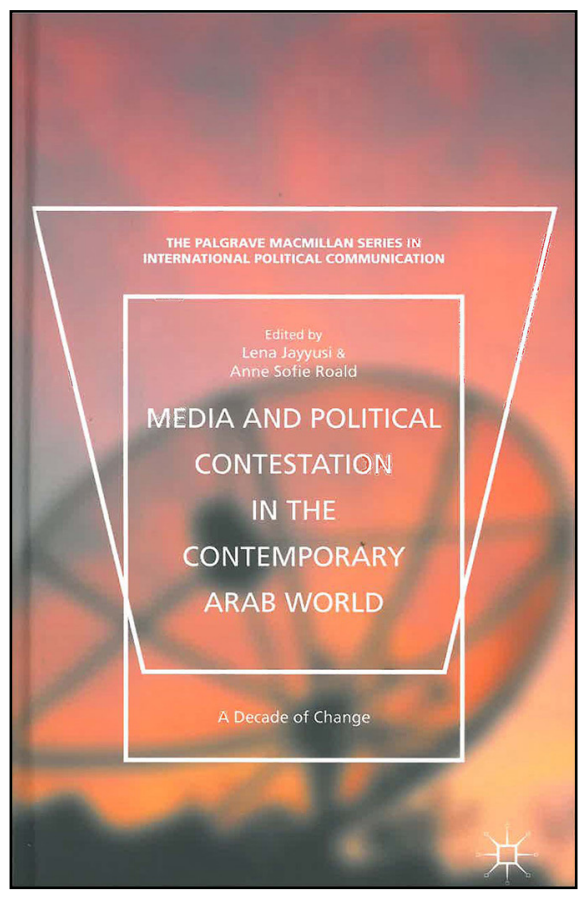

political dynamics play themselves out, primarily on two fronts: between the Israeli occupation and Palestinian society and within Palestinian society itself.' (pp. 106-107)

Caught between competing cultural forces, a television programme like Star Academy becomes not a tacky piece of reality television, but, as Kraidy demonsrates, a battle ground for different versions of modernity and, inconceivably to a western audience, a poetry competition, Amir al-shu'ara' becomes a runway hit.

Other authors in this volume examine the role of women on Arabic television. What, for instance, is the significance of whether a television celebrity covers her hair? To ask the question is to open a debate on feminism, the power relations between 
men and women, the manipulation of the question of female modesty by religious authorities and politicians. These are questions of great intricacy and this book opens them up and makes them understandable to a non-Arabic audience. Dr PHILIP CASS is reviews editor of Pacific Journalism Review.

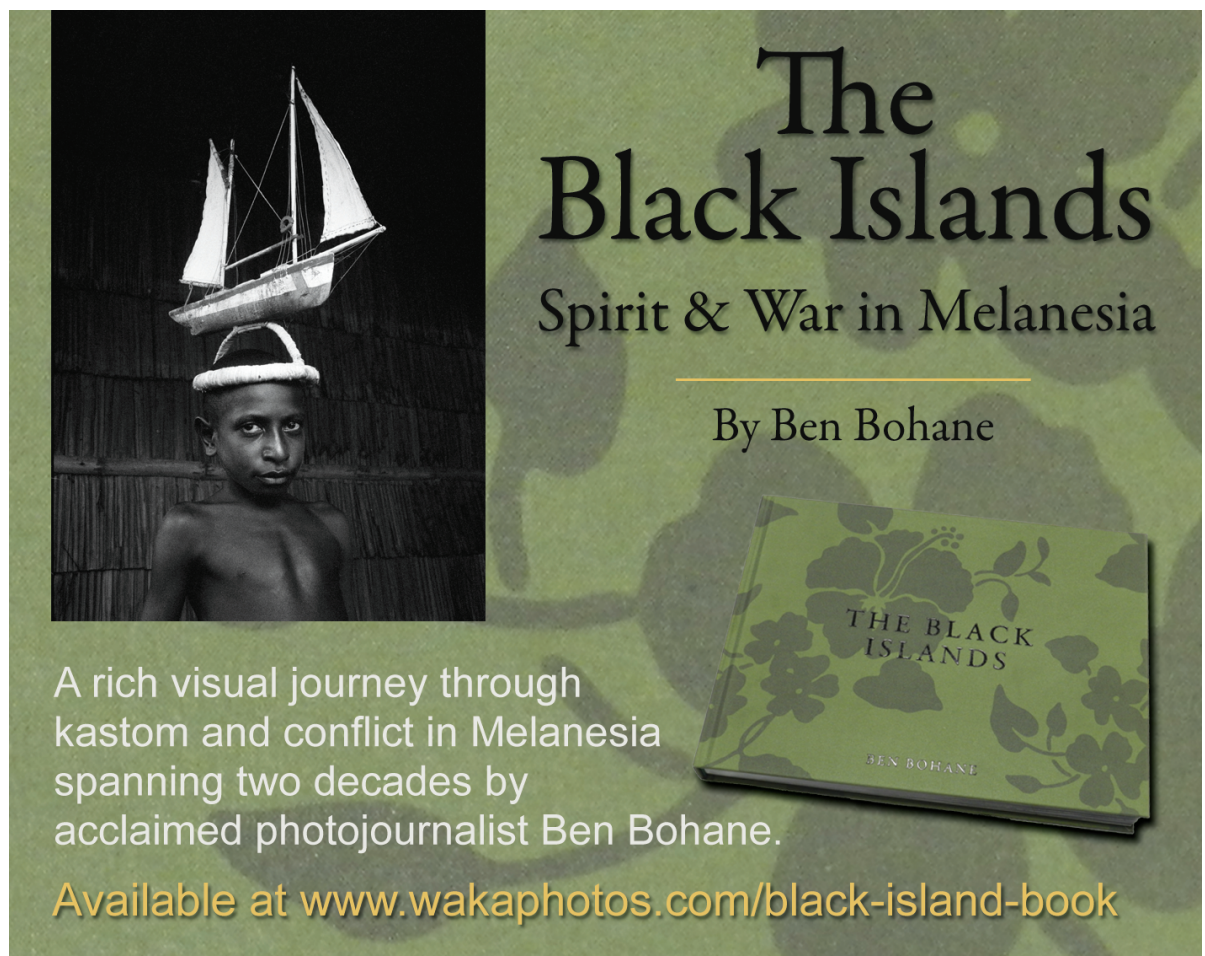

282 PACIFIC JOURNALISM REVIEW 23 (1) 2017 